\title{
Genetic evaluation of tidal swamp rice from South Kalimantan, Indonesia based on the agro-morphological markers
}

\author{
DINDIN HIDAYATUL MURSYIDIN ${ }^{1, \boldsymbol{v}}$, IZHAR KHAIRULLAH ${ }^{2}$ \\ ${ }^{1}$ Department of Biology, Faculty of Mathematics and Natural Sciences, Universitas Lambung Mangkurat. Jl. A. Yani Km. 36, Banjarbaru 70714, South \\ Kalimantan, Indonesia. Tel.: +62-511-4773112, "email: dindinhm@gmail.com \\ ${ }^{2}$ Indonesian Swamps Agricultural Research Institute. Jl. Kebun Karet, Loktabat, Banjarbaru 70712, South Kalimantan, Indonesia
}

Manuscript received: 21 August 2020. Revision accepted: 24 September 2020.

\begin{abstract}
Mursyidin DH, Khairullah I. 2020. Genetic evaluation of tidal swamp rice from South Kalimantan, Indonesia based on the agro-morphological markers. Biodiversitas 21: 4795-4803. A total of 71 cultivars of the tidal swamp rice (Oryza sativa L.), originated mainly from South Kalimantan, Indonesia, were evaluated agro-morphologically by using 26 qualitative and 13 quantitative traits. Based on these traits, this germplasm is generally low in diversity. However, three agro-morphological traits, namely the tillering abilities, seedling height, and diameter of the basal internode, shows the relatively highest diversity, shown by the Lakatan Putih, Pandak Putih, and Bayar Papuyu, respectively. The UPGMA and PCA revealed that this germplasm divided into six main clusters, where the sixth cluster is the largest with a total membership of 60 cultivars. The cluster analysis also revealed that Lakatan Siam is far separate from other cultivars. Thus, this finding might be useful in the future rice breeding programs, particularly in developing new rice cultivar for the tidal swamp areas.
\end{abstract}

Keywords: Genetic diversity, landrace, plant breeding, tidal swamp area

\section{INTRODUCTION}

Rice is germplasm that has been known and cultivated by humans for thousands of years (Silva et al. 2015). So it is not surprising that today, this plant has spread in more than 100 countries and become a staple food for more than half of the world's population (Ismail 2013, Anumalla et al. 2015), as well as a barometer in food security programs (Caballero-Anthony 2015). The food security is defining as a condition where all people have adequate amounts of safe and nutritious food for their health and active life (Caballero-Anthony 2015). So it is not surprising again that these countries must be able to maintain the availability of their food to avoid the threat of food insecurity. In other words, they must conduct various efforts for food security or rice self-sufficiency programs.

Extensification is a program that carried out by many countries to realize food security or rice self-sufficiency programs (Nkamleu 2011). In general, the program aimed at increasing agricultural output by expanding the new agricultural land, such as clearing forests and shrubs, as well as marginal areas (Nkamleu 2011; Sulakhudin and Hatta 2018). The swamps, though fragile, turn out to have enormous potential for future agricultural purposes. It is mainly related to the extent and distribution, as well as the potential for germplasm it has. In Indonesia, for example, there is 33.41-39.10 million ha of swamps, which can be useful for agricultural purposes and spread over several large islands, including Sumatra, Kalimantan, and Papua (Sulakhudin and Hatta 2018).

Regarding the potential resources of swamps, there is a great variety of genetic resources that are very interesting to develop, one of which is the tidal swamp rice (Oryza sativa L.) landraces. In general, this germplasm has relatively low productivity, only two tons per hectare (Mursyidin et al. 2017). However, they have adapted well to swamp conditions, such as submergence, low $\mathrm{pH}$, heavy metal contamination, and salinity (Sinaga et al. 2014, Mursyidin et al. 2017).

In Indonesia, it estimated more than 300 local rice cultivars found in swamps (Khairullah et al. 2008). The Indonesian Swamps Agricultural Research Institute (BALITTRA) has explored this germplasm from 1994 to 2002, mainly in the swamp areas of Kalimantan and Sumatra, and obtained as many as 221 swamp rice cultivars. Following this number, 175 originated from tidal swamps, while the remainder is from 'lebak' (Khairullah et al. 2008).

Tidal swamp rice has been known for a long time, by the local people and farmers of South Kalimantan, especially the Banjar tribe. Since 1920, the local people have known, and cultivated the Bayar as one of the swamp rice cultivars, as well as Lemo (Mursyidin et al. 2017). Khairullah (2020) reported that besides these two cultivars (Bayar and Lemo), the Siam and Pandak are also well known in South Kalimantan. However, most of the germplasm has not been well characterized and underutilized optimally in the rice breeding programs. 
This study aims to evaluate the genetic diversity of tidal swamp rice in South Kalimantan, Indonesia using agromorphological markers. While this marker has certain limitations, it still commonly used in analyzing the genetic diversity of local rice. According to Wijayawardhana et al. (2015), this marker is low cost and very easy to apply. Besides, because this marker is the result of gene expression, its existence will always be used by breeders to evaluate local rice. Hence, our results may be useful in supporting rice plant breeding programs, particularly the development of tidal swamp rice in the future.

\section{MATERIALS AND METHODS}

\section{Plant materials}

A total of 71 cultivars of the tidal swamp rice landraces (Table 1), comprises 70 from 18 sites of the South Kalimantan Province, Indonesia (Figure 1) and one as a comparative sample, namely Kutut from the Lampung Province of Sumatra Island, Indonesia, was used in the study.

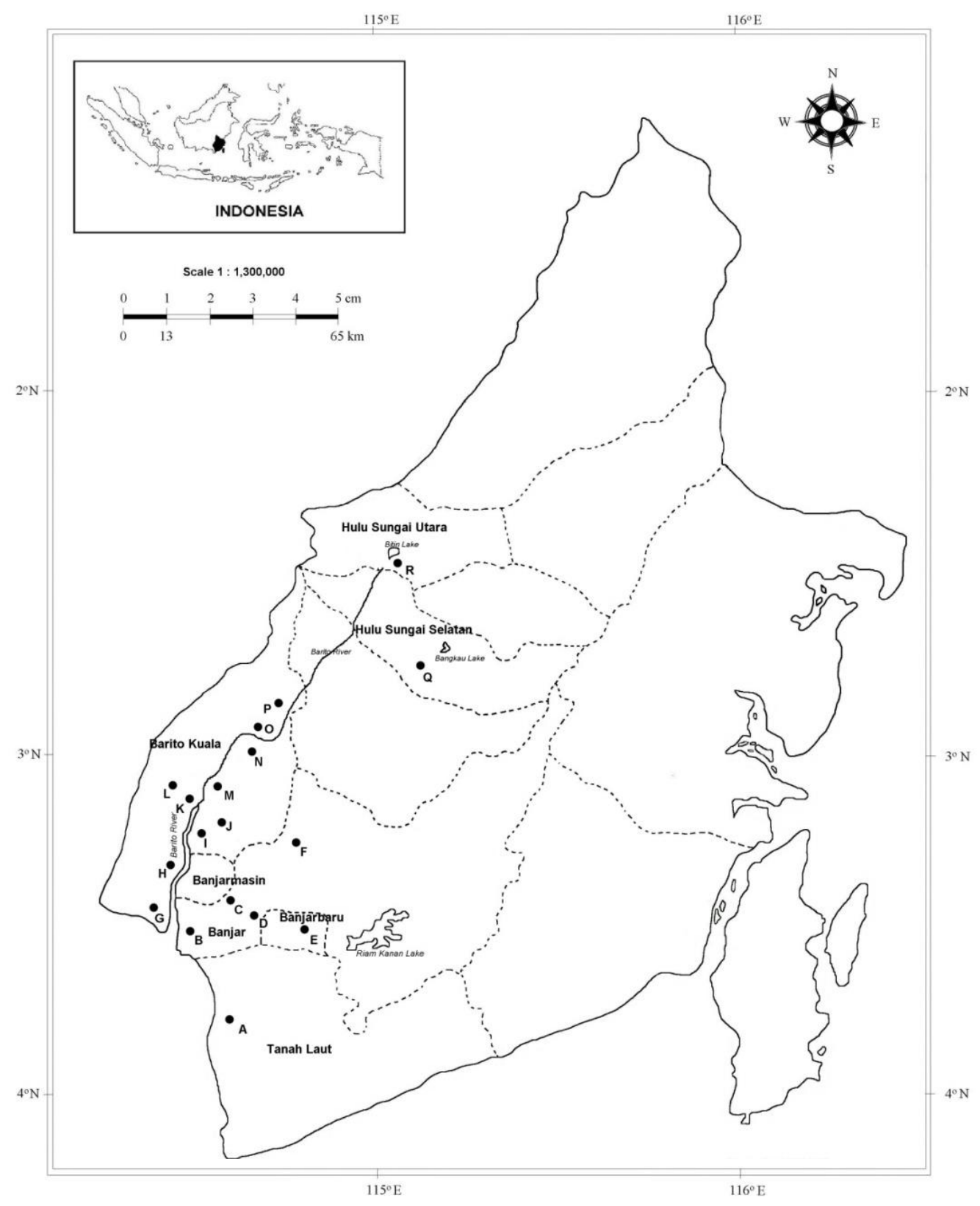

Figure 1. Maps of South Kalimantan, Indonesia, showing the sampling locations (marked) where the tidal swamp rice were collected. A. Kurau, B. Aluh-Aluh, C. Kertak Hanyar, D. Gambut, E. Banjarbaru, F. Sungai Tabuk, G. Tabunganen, H. Tamban, I. Alalak, J. Mandastana, K. Anjir Pasar, L. Anjir Muara, M. Belawang, N. Rantau Badauh, O. Barambai, P. Marabahan, Q. Kalumpang, R. Babirik 
Table 1. List of tidal swamp rice landraces used in the study

\begin{tabular}{|c|c|}
\hline Cultivar & Origin (District/Regency/Province) \\
\hline Adil Kuning & Babirik, Hulu Sungai Utara, South Kalimantan \\
\hline Bayar Pahit & Gambut, Banjar, South Kalimantan \\
\hline Bayar Palas & Tabunganen, Barito Kuala, South Kalimantan \\
\hline Вауат Рариуи & Aluh-Aluh, Banjar, South Kalimantan \\
\hline Jurut & Barambai, Barito Kuala, South Kalimantan \\
\hline Kawi & Marabahan, Barito Kuala, South Kalimantan \\
\hline Kutut* & Lampung, Sumatra \\
\hline Lakatan & Mandastana, Barito Kuala, South Kalimantan \\
\hline Lakatan Gadur & Sungai Tabuk, Banjar, South Kalimantan \\
\hline Lakatan Hirang & Barambai, Barito Kuala, South Kalimantan \\
\hline Lakatan Pacar & Alalak, Barito Kuala, South Kalimantan \\
\hline Lakatan Putih & Kalumpang, Hulu Sungai Selatan, South Kalimantan \\
\hline Lakatan Siam & Kertak Hanyar, Banjar, South Kalimantan \\
\hline Lemo Kwatik & Alalak, Barito Kuala, South Kalimantan \\
\hline Lemo Putih & Kertak Hanyar, Banjar, Kalimantan Selatan \\
\hline Pal 11 & Kertak Hanyar, Banjar, South Kalimantan \\
\hline Pal 6 & Kertak Hanyar, Banjar, South Kalimantan \\
\hline Palon & Alalak, Barito Kuala, South Kalimantan \\
\hline Pandak & Banjarbaru, South Kalimantan \\
\hline Pandak Arjuna & Tamban, Barito Kuala, South Kalimantan \\
\hline Pandak Kambang & Kalumpang, Hulu Sungai Selatan, South Kalimantan \\
\hline Pandak Kembang & Barambai, Barito Kuala, South Kalimantan \\
\hline Pandak Manggar & Marabahan, Barito Kuala, South Kalimantan \\
\hline Pandak Putih & Barambai, Barito Kuala, South Kalimantan \\
\hline Pirak & Alalak, Barito Kuala, South Kalimantan \\
\hline Raden Rata & Tabunganen, Barito Kuala, South Kalimantan \\
\hline Siam Adus & Mandastana, Barito Kuala, South Kalimantan \\
\hline Siam Arjuna & Tamban, Barito Kuala, South Kalimantan \\
\hline Siam Babirik & Babirik, Hulu Sungai Utara, South Kalimantan \\
\hline Siam Birik & Babirik, Hulu Sungai Utara, South Kalimantan \\
\hline Siam Brandal & Gambut, Banjar, South Kalimantan \\
\hline Siam Ganal & Anjir Pasar, Barito Kuala, South Kalimantan \\
\hline Siam Gumpal & Gambut, Banjar, South Kalimantan \\
\hline Siam Halus & Belawang, Barito Kuala, South Kalimantan \\
\hline Siam Karangdukuh & Anjir Pasar, Barito Kuala, South Kalimantan \\
\hline Siam Karangdukuh Kuning & Barambai, Barito Kuala, South Kalimantan \\
\hline Siam Karta & Kertak Hanyar, Banjar, South Kalimantan \\
\hline Siam Klubut & Tabunganen, Barito Kuala, South Kalimantan \\
\hline Siam Kretek & Rantau Badauh, Barito Kuala, South Kalimantan \\
\hline Siam Lantik & Anjir Muara, Barito Kuala, South Kalimantan \\
\hline Siam Lantik Merah & Anjir Muara, Barito Kuala, South Kalimantan \\
\hline Siam Lantik Putih & Rantau Badauh, Barito Kuala, South Kalimantan \\
\hline Siam Palas & Kertak Hanyar, Banjar, South Kalimantan \\
\hline Siam Panangah & Gambut, Banjar, South Kalimantan \\
\hline Siam Pandak & Banjarbaru, South Kalimantan \\
\hline Siam Pangling & Mandastana, Barito Kuala, South Kalimantan \\
\hline Siam Perak & Belawang, Barito Kuala, South Kalimantan \\
\hline Siam Perak Ganal & Anjir Pasar, Barito Kuala, South Kalimantan \\
\hline Siam Perak Halus & Anjir Muara, Barito Kuala, South Kalimantan \\
\hline Siam Pontianak Halus & Kertak Hanyar, Banjar, South Kalimantan \\
\hline Siam Pontianak Tinggi & Kertak Hanyar, Banjar, South Kalimantan \\
\hline Siam Puntal & Kertak Hanyar, Banjar, South Kalimantan \\
\hline Siam Puntal-2 & Alalak, Barito Kuala, South Kalimantan \\
\hline Siam Putih & Anjir Muara, Barito Kuala, South Kalimantan \\
\hline Siam $P X$ & Kertak Hanyar, Banjar, South Kalimantan \\
\hline Siam Randah & Kalumpang, Hulu Sungai Selatan, South Kalimantan \\
\hline Siam Randah Kuning & Rantau Badauh, Barito Kuala, South Kalimantan \\
\hline Siam Randah Putih & Tamban, Barito Kuala, South Kalimantan \\
\hline Siam Rata & Kertak Hanyar, Banjar, South Kalimantan \\
\hline Siam Sabar & Gambut, Banjar, South Kalimantan \\
\hline Siam Sebelas & Sungai Tabuk, Banjar, South Kalimantan \\
\hline Siam Suruk & Gambut, Banjar, South Kalimantan \\
\hline Siam Tanggung & Kurau, Tanah Laut, South Kalimantan \\
\hline Siam Teladan & Kertak Hanyar, Banjar, South Kalimantan \\
\hline Siam Ubi & Tamban, Barito Kuala, South Kalimantan \\
\hline Siam Unus & Sungai Tabuk, Banjar, South Kalimantan \\
\hline Siam Unus Kuning & Anjir Pasar, Barito Kuala, South Kalimantan \\
\hline Siam Unus Putih & Kertak Hanyar, Banjar, South Kalimantan \\
\hline Siam Wol & Tabunganen, Barito Kuala, South Kalimantan \\
\hline Unus Gampa & Rantau Badauh, Barito Kuala, South Kalimantan \\
\hline Unus Organik & Anjir Pasar, Barito Kuala, South Kalimantan \\
\hline
\end{tabular}

\section{Sample preparation and observation}

All rice samples were planted and maintained in a Research Station of Indonesian Swamp Agricultural Research Institute (BALITTRA), Indonesia, precisely at Balandean, Barito Kuala, Kalimantan Selatan by twenty replicates, for eight months from January to August 2019. This germplasm was characterized by a total of 39 agromorphological traits, comprises of 26 qualitative (Table 2) and 13 quantitative (Table 3) traits, using the guidance of rice descriptors (Biodiversity International 2007).

\section{Data analysis}

All agro-morphological data were analyzed using a multivariate statistical method. The standardized ShannonWeaver diversity index $\left(H^{\prime}\right)$ was used to determine the genetic diversity of this germplasm, following an equation (Mengistu et al. 2015):

$$
H=-\overbrace{i=1}^{n} p i \ln p i
$$

Where; $H$ is the diversity index, $p_{\mathrm{i}}$ is the proportion of the entries in the $i^{\text {th }}$ class of an $n$-class trait, $n$ is the number of the phenotypic classes for a trait, $p_{\mathrm{i}}$ is the relative frequency, and $\ln p_{\mathrm{i}}$ is the natural logarithm of this proportion. Each value of $H$ was standardized by conversion to a relative phenotypic diversity index $\left(H^{\prime}\right)$ by division by $H_{\max }=\ln (\mathrm{n})$ to express the $H^{\prime}$ value in the range of $0-1$.

$$
H^{\prime}=H / H_{\max }
$$

The diversity index was classified as high $\left(H^{\prime} \geq 0.60\right)$, intermediate $\left(0.40 \leq H^{\prime} \leq 0.60\right)$, or low $\left(0.10 \leq H^{\prime} \leq 0.40\right)$, as described in Mengistu et al. (2015). The principal components (PCA) and cluster analyses (CA) were also conducted to recognize the distinctiveness of the traits that contributed to the genetic diversity and reconstructed their relationships, respectively. In the PCA, the proportion of a variance criterion was used to identify the different principal components that contributed to the total variation in the dataset. In CA, the distance matrix was generated using the Euclidean distance coefficients, and the dendrogram was reconstructed by the unweighted pair group method with arithmetic mean (UPGMA). Both analyses were done using MVSP ver. 3.1 (Kovach 2007).

\section{RESULTS AND DISCUSSION}

\section{Results}

In general, the tidal swamp rice of South Kalimantan has a low genetic diversity, both for qualitative (Table 2) and quantitative (Table 3 ) traits. It is shown by the level of its genetic diversity, 0.11 for the qualitative and 0.29 for the quantitative traits. However, lemma and palea (husk) color is the highest diversity (0.72) than others. 
Table 2. Genetic diversity $\left(H^{\prime}\right.$ index) of the tidal swamp rice based on qualitative characters

\begin{tabular}{|c|c|c|}
\hline Characters & Code & H' Index \\
\hline Vegetative Vigor & $\mathrm{A}$ & $0.25^{\mathrm{a}}$ \\
\hline Culm Strength & $\mathrm{B}$ & $0.45^{\mathrm{b}}$ \\
\hline Leaf Senescence & $\mathrm{C}$ & 0.00 \\
\hline Panicle Exertion & $\mathrm{D}$ & $0.20^{\mathrm{a}}$ \\
\hline Panicle Threshability & $\mathrm{E}$ & 0.00 \\
\hline Phenotypic Acceptability & $\mathrm{F}$ & 0.00 \\
\hline Leaf Blade Pubescence & $\mathrm{G}$ & 0.00 \\
\hline Leaf Blade Color & $\mathrm{H}$ & 0.00 \\
\hline Basal Leaf Sheath Color & I & 0.00 \\
\hline Leaf Angle & J & 0.00 \\
\hline Flag Leaf Angle & $\mathrm{K}$ & 0.00 \\
\hline Ligule Color & $\mathrm{L}$ & 0.00 \\
\hline Ligule Shape & M & 0.00 \\
\hline Collar Color & $\mathrm{N}$ & 0.00 \\
\hline Auricle Color & $\mathrm{O}$ & 0.00 \\
\hline Culm Angle & $\mathrm{P}$ & $0.37^{\mathrm{a}}$ \\
\hline Culm Internode Color & Q & 0.00 \\
\hline Panicle Type & $\mathrm{R}$ & 0.00 \\
\hline Secondary Branching of Panicles & S & $0.43^{\mathrm{b}}$ \\
\hline Panicle Axis & $\mathrm{T}$ & 0.00 \\
\hline Awning & $\mathrm{U}$ & 0.00 \\
\hline Apiculus Color & $\mathrm{V}$ & 0.00 \\
\hline Lemma and Palea Color & $\mathrm{W}$ & $0.72^{\mathrm{c}}$ \\
\hline Lemma and Palea Pubescence & $\mathrm{X}$ & 0.00 \\
\hline Sterile Lemma Color & $\mathrm{Y}$ & 0.00 \\
\hline Endosperm type & $\mathrm{Z}$ & $0.37^{\mathrm{a}}$ \\
\hline Average & $0.11^{\mathrm{a}}$ & \\
\hline
\end{tabular}

Slightly different from the qualitative traits, 3 of the 13 quantitative showed relatively high diversity, namely tillering ability (0.59), seedling height (0.49), and diameter of basal internodes (0.57). Based on Table 3, the Lakatan Putih is tidal swamp rice that has a high tillering ability (28 tillers), whereas Pandak Putih and Bayar Papuyu for the traits of seedling height and diameter of basal internodes, $90 \mathrm{~cm}$ and $8.9 \mathrm{~mm}$, respectively.
The PCA (Table 4), shows that the first component of the analysis, seven quantitative traits are contributed positively into the genetic diversity of tidal swamp rice, including lodging incidence, plant height, leaf length, leaf width, culm length, and grain length, as well as the diameter of the basal internode. In the second component, four qualitative traits (vegetative vigor, culm strength, secondary branching of the panicle, lemma, and palea color) and five quantitative traits (tillering ability, plant height, culm number, grain width, the diameter of basal internode) are also contributed positively into the diversity. In this case, the traits of tillering ability, culm number, and grain width are the highest contributor to its diversity.

The UPGMA (Figure 2) shows that the tidal swamp rice of South Kalimantan is divided into six main clusters, at a similarity coefficient of 0.71 . Based on Figure 2, the sixth cluster is the largest, which consists of sixty landraces, and most of them are the Siam group. Furthermore, at the similarity coefficient of 0.75 , the sixth cluster is divided into two subgroups, consisting of 14 and 46 cultivars, respectively. Based on the dendrogram (Figure 2), it also is seen that Siam Puntal-2 has a very close relationship, with Siam Karangdukuh Kuning, at a similarity coefficient of 0.96. Whereas, the Lakatan Siam and Siam Puntal-1 are the farthest, with a similarity coefficient of 0.50 .

The PCA (Figure 3), shows that the groupings of local rice are influenced by the specific traits (see vector lines). For example, the cultivars of Kawi, Siam Ubi, and Pal 11 are closely related due to the character of the tillering ability $(A A)$ and culm number $(A I)$. Other examples, namely Siam Arjuna, Siam Putih, Siam Sebelas, and Siam Karangdukuh are grouped by the panicle exsertion, maturity, secondary branching of panicles, and lemma and palea color (Figure 3). Based on the scatter plot, some cultivars are far related to others, such as Siam Randah, Siam Puntal-1, and Lakatan Siam.

Table 3. Genetic diversity (H index) of tidal swamp rice based on quantitative characters

\begin{tabular}{|c|c|c|c|c|c|c|}
\hline Characters & Code & $\begin{array}{l}\text { Lowest } \\
\text { value }\end{array}$ & Cultivar & $\begin{array}{l}\text { Highest } \\
\text { value }\end{array}$ & Cultivar & H' index \\
\hline Tillering ability & $\overline{\mathrm{AA}}$ & 9 & Pandak Putih & 28 & Lakatan Putih & $0.59^{b}$ \\
\hline Lodging Incidence (\%) & $\mathrm{AB}$ & 0 & Siam Perak Halus and 33 others & 60 & Siam Puntal-1 & $0.12^{\mathrm{a}}$ \\
\hline Plant Height $(\mathrm{cm})$ & $\mathrm{AC}$ & 106 & Siam Perak halus & 200 & Pal 11 & $0.43^{\mathrm{b}}$ \\
\hline Maturity (days) & $\mathrm{AD}$ & 270 & $\begin{array}{l}\text { Siam Rata, Unus Organik, } \\
\text { Siam Pangling }\end{array}$ & 315 & Siam Gumpal & $0.33^{\mathrm{a}}$ \\
\hline Seedling Height $(\mathrm{cm})$ & $\mathrm{AE}$ & 41 & Lemo Putih & 90 & Pandak Putih & $0.49^{\mathrm{b}}$ \\
\hline Leaf Length $(\mathrm{cm})$ & $\mathrm{AF}$ & 33.6 & Siam Randah & 66.0 & Unus Gampa & $0.14^{\mathrm{a}}$ \\
\hline Leaf Width (mm) & AG & 9 & Siam Randah, Pirak & 16 & Siam Brandal & $0.17^{\mathrm{a}}$ \\
\hline Culm Length $(\mathrm{cm})$ & $\mathrm{AH}$ & 85 & Siam Perak Halus & 154 & Lemo Kwatik & $0.13^{\mathrm{a}}$ \\
\hline Culm Number & AI & 9 & Pandak Putih & 25 & Kawi, Pandak Kembang, Palon & $0.37^{\mathrm{a}}$ \\
\hline Grain Length (mm) & AJ & 75 & Siam Putih & 94 & Lakatan & $0.19^{\mathrm{a}}$ \\
\hline Grain Width (mm) & $\mathrm{AK}$ & 1 & Siam Unus Putih and 8 others & 1.9 & $\begin{array}{l}\text { Siam Ganal, Bayar Pahit, } \\
\text { Lemo Kwatik, Pandak Putih, } \\
\text { Pandak Kembang }\end{array}$ & $0.12^{\mathrm{a}}$ \\
\hline Grain ratio & $\mathrm{AL}$ & 4.3 & Pandak Kembang & 5.4 & Pandak Kambang & $0.18^{\mathrm{a}}$ \\
\hline $\begin{array}{l}\text { Diameter of Basal } \\
\text { Internode (mm) }\end{array}$ & $\mathrm{AM}$ & 4.9 & $\begin{array}{l}\text { Siam Randah, Siam Pontianak } \\
\text { Halus }\end{array}$ & 8.9 & Вауаг Рариуи & $0.57^{\mathrm{b}}$ \\
\hline Average & & & & & & $0.29^{\mathrm{a}}$ \\
\hline
\end{tabular}




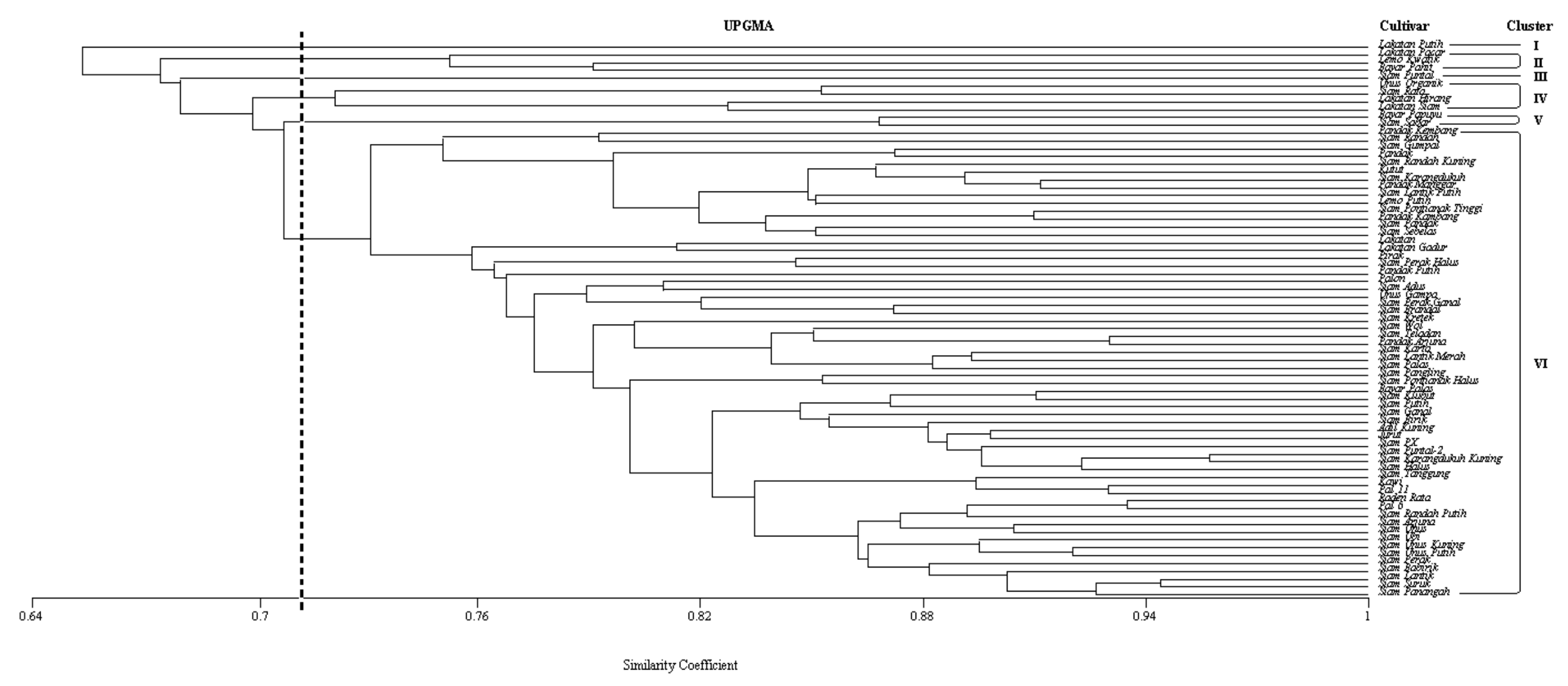

Figure 2. The genetic relationship of tidal swamp rice landraces based on UPGMA. This germplasm clustered into six main groups 


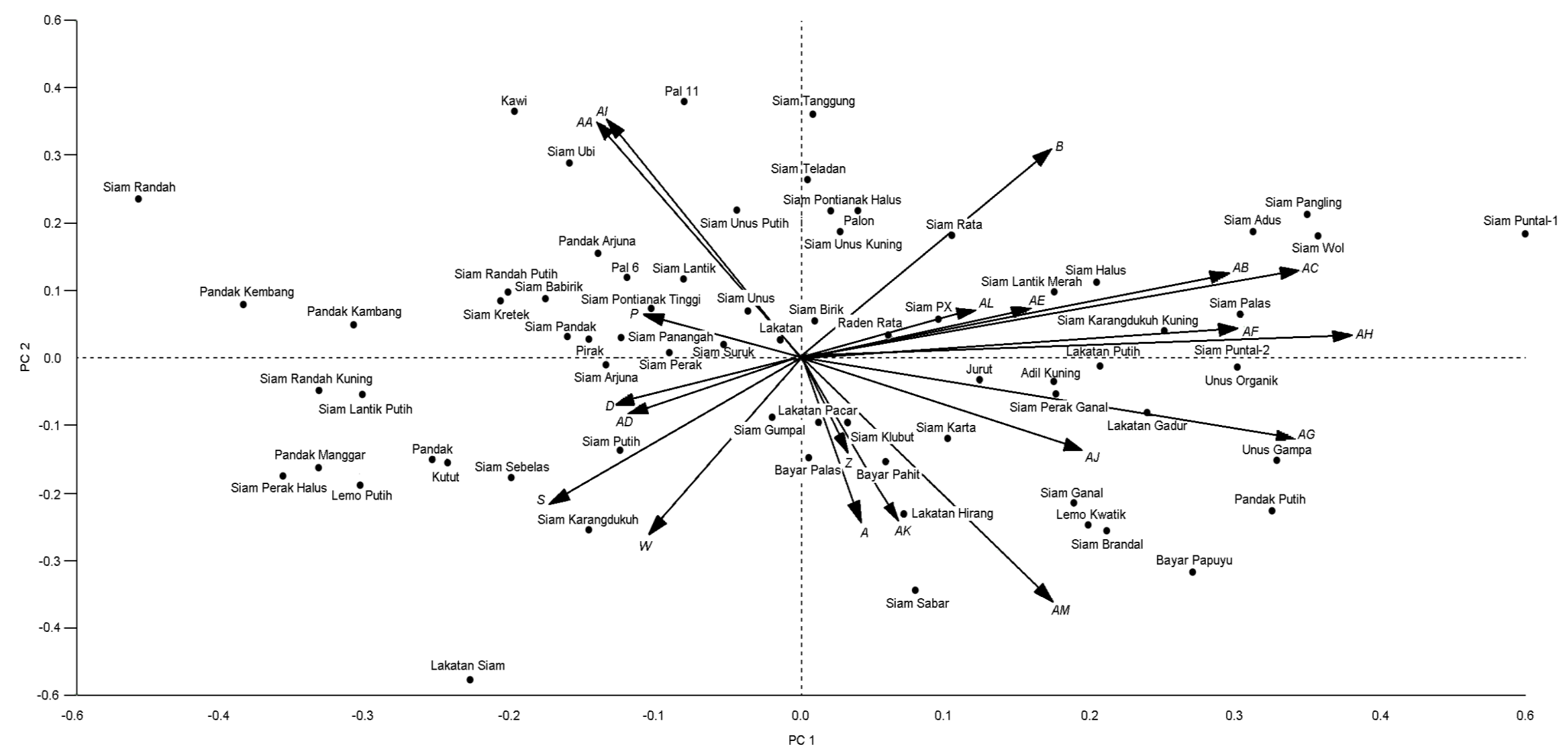

Figure 3. Clustering of the tidal swamp rice landraces based on PCA. Vector indicated the morphological traits, code of each trait could be seen in Table 4 . 
Table 4. PCA scores of tidal swamp rice based on qualitative characters

\begin{tabular}{|c|c|c|c|c|c|c|}
\hline \multirow{2}{*}{ Characters } & \multirow{2}{*}{ Code } & \multicolumn{5}{|c|}{ Components } \\
\hline & & PC1 & PC2 & PC 3 & PC 4 & PC 5 \\
\hline \multicolumn{7}{|l|}{ Qualitative traits } \\
\hline Vegetative vigor & A & 0.051 & $-0.266^{*}$ & -0.053 & -0.081 & $-0.434^{*}$ \\
\hline Culm strength & $\mathrm{B}$ & 0.199 & $0.344^{*}$ & -0.073 & $-0.206^{*}$ & 0.026 \\
\hline Leaf senescence & $\mathrm{C}$ & 0.000 & 0.000 & 0.000 & 0.000 & 0.000 \\
\hline Panicle exsertion & $\mathrm{D}$ & -0.159 & -0.077 & 0.031 & 0.130 & 0.195 \\
\hline Panicle threshability & $\mathrm{E}$ & 0.000 & 0.000 & 0.000 & 0.000 & 0.000 \\
\hline Phenotypic acceptability & $\mathrm{F}$ & 0.000 & 0.000 & 0.000 & 0.000 & 0.000 \\
\hline Leaf blade pubescence & G & 0.000 & 0.000 & 0.000 & 0.000 & 0.000 \\
\hline Leaf blade color & $\mathrm{H}$ & 0.000 & 0.000 & 0.000 & 0.000 & 0.000 \\
\hline Basal leaf sheath color & I & 0.000 & 0.000 & 0.000 & 0.000 & 0.000 \\
\hline Leaf angle & $\mathrm{J}$ & 0.000 & 0.000 & 0.000 & 0.000 & 0.000 \\
\hline Flag leaf angle & $\mathrm{K}$ & 0.000 & 0.000 & 0.000 & 0.000 & 0.000 \\
\hline Ligule color & $\mathrm{L}$ & 0.000 & 0.000 & 0.000 & 0.000 & 0.000 \\
\hline Ligule shape & M & 0.000 & 0.000 & 0.000 & 0.000 & 0.000 \\
\hline Collar color & $\mathrm{N}$ & 0.000 & 0.000 & 0.000 & 0.000 & 0.000 \\
\hline Auricle color & $\mathrm{O}$ & 0.000 & 0.000 & 0.000 & 0.000 & 0.000 \\
\hline Culm angle & $\mathrm{P}$ & -0.114 & 0.068 & 0.093 & $-0.333^{*}$ & 0.090 \\
\hline Culm internode color & Q & 0.000 & 0.000 & 0.000 & 0.000 & 0.000 \\
\hline Panicle type & $\mathrm{R}$ & 0.000 & 0.000 & 0.000 & 0.000 & 0.000 \\
\hline Secondary branching of panicles & $\mathrm{S}$ & -0.198 & $-0.244^{*}$ & 0.174 & $-0.217^{*}$ & $-0.257^{*}$ \\
\hline Panicle axis & $\mathrm{T}$ & 0.000 & 0.000 & 0.000 & 0.000 & 0.000 \\
\hline Awning & $\mathrm{U}$ & 0.000 & 0.000 & 0.000 & 0.000 & 0.000 \\
\hline Apiculus color & $\mathrm{V}$ & 0.000 & 0.000 & 0.000 & 0.000 & 0.000 \\
\hline Lemma and palea color & $\mathrm{W}$ & -0.125 & $-0.288^{*}$ & $0.279^{*}$ & 0.131 & 0.063 \\
\hline Lemma and palea pubescence & $\mathrm{X}$ & 0.000 & 0.000 & 0.000 & 0.000 & 0.000 \\
\hline Sterile lemma color & $\mathrm{Y}$ & 0.000 & 0.000 & 0.000 & 0.000 & 0.000 \\
\hline Endosperm type & $\mathrm{Z}$ & 0.039 & -0.151 & $0.266^{*}$ & 0.008 & $-0.341^{*}$ \\
\hline \multicolumn{7}{|l|}{ Quantitative traits } \\
\hline Tillering ability & AA & -0.183 & $0.383^{*}$ & $0.275^{*}$ & $0.259^{*}$ & $-0.323^{*}$ \\
\hline Lodging incidence $(\%)$ & $\mathrm{AB}$ & $0.347^{*}$ & 0.140 & -0.099 & $-0.320^{*}$ & $-0.267^{*}$ \\
\hline Plant height $(\mathrm{cm})$ & $\mathrm{AC}$ & $0.255^{*}$ & $0.210^{*}$ & 0.049 & $0.261^{*}$ & -0.051 \\
\hline Maturity (days) & $\mathrm{AD}$ & -0.138 & -0.087 & -0.014 & $0.435^{*}$ & $0.300^{*}$ \\
\hline Seedling height $(\mathrm{cm})$ & $\mathrm{AE}$ & 0.178 & 0.091 & 0.020 & $0.250^{*}$ & 0.124 \\
\hline Leaf length $(\mathrm{cm})$ & $\mathrm{AF}$ & $0.337^{*}$ & 0.057 & -0.057 & 0.125 & 0.100 \\
\hline Leaf width (mm) & $\mathrm{AG}$ & $0.397^{*}$ & -0.121 & 0.032 & 0.040 & 0.078 \\
\hline Culm length $(\mathrm{cm})$ & $\mathrm{AH}$ & $0.412^{*}$ & 0.043 & 0.003 & 0.196 & -0.099 \\
\hline Culm number & AI & -0.176 & $0.381^{*}$ & $0.262^{*}$ & $0.258^{*}$ & $-0.304^{*}$ \\
\hline Grain length (mm) & AJ & $0.231^{*}$ & -0.139 & $0.476^{*}$ & 0.014 & 0.012 \\
\hline Grain width (mm) & $\mathrm{AK}$ & 0.079 & $-0.256^{*}$ & $-0.220^{*}$ & $0.296^{*}$ & $-0.330^{*}$ \\
\hline Grain ratio & $\mathrm{AL}$ & 0.141 & 0.084 & $0.581^{*}$ & $-0.223^{*}$ & $0.261^{*}$ \\
\hline Diameter of basal internode (mm) & $\mathrm{AM}$ & $0.204^{*}$ & $-0.389^{*}$ & 0.172 & 0.098 & 0.015 \\
\hline Eigenvalues & & 3.612 & 2.703 & 1.978 & 1.734 & 1.453 \\
\hline Percentage & & 18.058 & 13.515 & 9.892 & 8.668 & 7.264 \\
\hline Cum. Percentage & & 18.058 & 31.572 & 41.464 & 50.132 & 57.396 \\
\hline
\end{tabular}

Note: ${ }^{*}$ contributed to genetic diversity

\section{Discussion}

Genetic diversity is valuable in supporting breeding programs, as well as the conservation of natural resources (Zhang et al. 2011). According to Frankham et al. (2004), genetic diversity can be measured based on morphological, biochemical, and molecular types of information. The Shannon-Weaver index is one method that can apply in determining this diversity, widely in ecology (Morris et al. 2014), particularly for comparing species diversity between various habitats (Ortiz-Burgos 2016). To date, however, this method is also used in taxonomic and genetics, for example, in determining the phenotypic diversity of durum wheat (Triticum turgidum var. durum) landraces (Mengistu et al. 2015, Iannucci and Codianni 2019) and barley (Hordeum vulgare L. subsp. vulgare) landraces (Bouhaouel et al. 2019).

In this study, using the Shannon-Weaver index, the tidal swamp rice of South Kalimantan is generally low in genetic diversity, both for qualitative and quantitative traits. However, some characters show high genetic diversity, such as lemma and palea color (Table 2), as well as three other quantitative, including tillering abilities, seedling height, and diameter of basal internode (Table 3). 
In the plant breeding program, those traits are the key characters in the development of new superior rice cultivars.

According to Constantino et al. (2015), the tillering ability is one of the quantitative traits that contributed positively to rice productivity (yield). Hussain et al. (2014), states that tillering ability can act as a determinant of stem architecture and grain production in Poaceae. In rice plants, the number of panicles is very dependent on the number of tillers. In other words, the higher number of tillers, the higher number of harvests produced (Constantino et al. 2015). Hence, cultivars with the highest ability of tiller number are the main goal in breeding programs since the 18th century for the high yields (Liu et al. 2013). In this study, Lakatan Putih is a tidal swamp rice landraces that have the highest tillering ability, with 28 tillers (Table 3 ).

The diameter of basal internode is also suitable in the development of new superior rice cultivars, specifically for tidal swamp area. According to Wu et al. (2011), this trait is correlated positively with the level of lodging. In the breeding program, the last trait is a limiting factor that reduced the yielding potential, both in pure and hybrid lines. In this context, the lodging can affect the canopy for photosynthesis, increase respiration and susceptibility to disease, as well as reduce the translocation of nutrients and carbon in the rice grain (Wu et al. 2011).

Our previous study (Mursyidin et al. 2019), showed that the diameter of the stem or basal internode had a strong correlation with plant height and number of tillers, as well as panicle length. The larger-sized rice stem is also associated with the large size of panicles, as well as a higher number of grains per panicle (Wu et al. 2011). In this study, Bayar Рариyu is a cultivar with the highest diameter of basal internode $(8.9 \mathrm{~mm})$ (Table 3$)$.

Besides the tillering ability and diameter of basal internode, several other traits are also important in the development of new superior rice cultivars. Plant maturity, for example, is the most sought trait since the "green revolution" era for the development of the hybrid rice cultivars, around the 1960s (Zhao et al. 2016). Similarly, the grain ratio that represents the grain shape, is the main component in determining the grain weight and yields (Zheng et al. 2015). According to Calingacion et al. (2014), the grain shape is essential to consider in the program concerning the preferences of the local people and farmers. In South Kalimantan, for example, they have a very high preference (until 92.5\%) for the local rice with a slender grain shape (Wahdah and Langai 2011).

Based on the results, it also is known that local farmers in South Kalimantan recognize and named the tidal swamp rice based on the appearance of the husk (lemma and palea) color. Genetically, the difference of husk color may indicate genetic plasticity, well known as phenotypic plasticity. In brief, phenotypic plasticity can be defined as the ability of individual genotypes to produce different phenotypes when exposed to different environmental conditions (Fusco and Minelli 2010). In other words, phenotypic plasticity can also define as a phenomenon in which a given genotype may develop different states of a character or group of characters in different environments (Nayar 2014). Hence, it includes the possibility to modify developmental trajectories in response to specific environmental cues, and also the ability of an individual organism to change its phenotypic state in response to variations in environmental conditions (Fusco and Minelli 2010). According to Nayar (2014), this phenomenon is controlled by the specific allele or gene related to the conditions. For instance, the plant height variations are controlled by a gene regulator, namely rice plasticity 1 (RPL1), which located on chromosome 6 (Nayar 2014).

The emergence of phenotypic plasticity on the rice grain may also be related to the presence of transposon or transposable elements (TEs). According to Lisch (2013), there are some TEs in rice that appear to regulate nearby genes by antisense transcription. For example, an active rice transposon named miniature Ping (mPing) is associate with the mutability of a slender mutation of the glume-the seed structure that encloses and determines the shape of rice grain (Song and Cao 2017).

In the last part of the discussion, although the tidal swamp rice has a relatively low genetic diversity, the UPGMA and PCA are revealed that this germplasm has a relatively complex relationship. The results of cluster analysis show that these landraces are divided into six main clusters, where the sixth cluster is the largest and has a total membership of 60 cultivars (Figure 2). In this case, Lakatan Siam is far related to others. Whereas, Siam Puntal-2 and Siam Karangdukuh Kuning are a very close relationship, with a similarity coefficient of 0.96 . Interestingly, Kutut, a comparative sample from Lampung, Sumatra, has a very close relationship with Siam Karangdukuh, at the similarity coefficient of 0.91. Based on the results, it known that geographic location does not affect the grouping of this germplasm. According to Dwivedi et al. (2020), geographic location is unusually related to the emerge of genetic diversity. It means that genotypes originating from the same region are not always in the same cluster.

In-plant breeding, information on the far or close relationship of individuals can be useful as a reference in predicting the genetic diversity of the offspring (Acquaah 2017). In general, when individuals with distant relationships cross, the offspring may have high genetic diversity. Conversely, if the individual is a closely related cross, then the genetic is low (Acquaah 2017; TurnerHissong et al. 2020).

Nowadays, the crossing the parent with a close relationship is avoided, due to the inbreeding, such as the sloping symptom of yields and increasing the susceptibility to pests and diseases (de los Reyes 2019). Uddin et al. (2016), reported that as many as 333 new superior rice cultivars have a narrow genetic background to IR64 (a green revolution product). Thus, genetic diversity and the relationship of germplasm are very useful aspects of the future rice breeding programs, as well as the conservation efforts (Zhang et al. 2011). 


\section{ACKNOWLEDGEMENTS}

We are very thankful to the Director of the Indonesian Swamps Agricultural Research Institute (BALITTRA), Banjarbaru, South Kalimantan, Indonesia for permitting us to use his research station to plant and maintain all our rice samples.

\section{REFERENCES}

Acquaah G. 2017. Plant Breeding, Principles. In: Encyclopedia of Applied Plant Science. $2^{\text {nd }}$ ed. Elsevier Inc, New York, USA.

Anumalla M, Roychowdhury R, Geda CK, Mazid M, Rathoure AK. 2015 Utilization of plant genetic resources and diversity analysis tools for sustainable crop improvement with special emphasis on rice. Intl $\mathrm{J}$ Adv Res 3: 1155-1175

Biodiversity International. 2007. Descriptors for wild and cultivated rice (Oryza spp.). Bioversity International, Rome, Italy.

Bouhaouel I, Medini M, Belhadj H, Ayed OS, Jabri C, Slim H. 2019. Phenotypic diversity of barley (Hordeum vulgare L. subsp. vulgare) landraces from the Center and the South of Tunisia and identification of potential area of on-farm conservation. New Sci 66: 4157-4169.

Caballero-Anthony M. 2015. An introduction to non-traditional security studies: A transactional approach. Sage Publication Ltd., London.

Calingacion M, Laborte A, Nelson A, Resurreccion A, Concepcion JC, Daygon VD, et al. 2014. Diversity of global rice markets and the science required for consumer-targeted rice breeding. PLoS One 9 (1): e85106. DOI: 10.1371/journal.pone.0085106

Constantino KP, Gonzales EJ, Lazaro LM, Serrano EC, Samson BP. 2015. Plant height measurement and tiller segmentation of rice crops using image processing. Proceeding of DLSU Research Congress 3: 1-6.

de los Reyes BG. 2019. Genomic and epigenomic bases of transgressive segregation - New breeding paradigm for novel plant phenotypes Plant Sci 288: 110213. DOI: 10.1016/j.plantsci.2019.110213

Dwivedi SL, Goldman I, Ceccarelli S, Ortiz R. 2020. Advanced analytics, phenomics and biotechnology approach to enhance genetic gains in plant breeding. In: Sparks DL (ed). Advance in Agronomy. Elsevier Inc., New York.

Frankham R, Ballou JD, Briscoe DA. 2004. A Primer of Conservation Genetics. Cambridge University Press, Cambridge, UK.

Fusco G, Minelli A. 2010. Phenotypic plasticity in development and evolution: facts and concepts. Phil Trans Royal Soc B 365: 547-556.

Hussain A, Tavakol E, Horner DS, Munoz-Amatriain M, Muehlbauer GJ, Rossini L. 2014. Genetics of tillering in rice and barley. Plant Genome 7 (1): 1-20.

Iannucci A, Codianni P. 2019. Phenotypic parent selection within a Khorasan wheat collection and genetic variation in advanced breeding lines derived by hybridization with durum wheat. Front Plant Sci 10: 1460. DOI: $10.3389 /$ fpls.2019.01460

Ismail AM. 2013. Flooding and submergence tolerance, in Genomics and Breeding for Climate-Resilient Crops. C. Kole (ed). Springer, Berlin.

Khairullah I. 2020. Indigenous knowledge cultivation of local rice varieties "Siam Mutiara" and "Siam Saba" at tidal swampland. BIO Web Conf 2: 01007. DOI: 10.1051/bioconf/20202001007.

Khairullah I, William E, Nurtirtayani. 2008. Genetic potential of crops germplasm in swamps area. Indonesian Swampland Agriculture Research Institute, Banjarbaru, Indonesia. [Indonesian]

Kovach WL. 2007. MVSP 3.1: Multivariate Statistical Package. Kovach Computing Services, Wales, UK.

Lisch D. 2013. How important are transposons for plant evolution?. Nat Rev Genet 14 (1): 49-61. DOI: 10.1038/nrg3374

Liu Y, Yu L, Tong J, Ding J, Wang R, Lu Y, Xiao L. 2013. Tiller number is altered in the ascorbic acid-deficient rice suppressed for 1 galactono-1,4-lactone dehydrogenase. J Plant Physiol 170 (4): 389 396. DOI: 10.1016/j.jplph.2012.11.019.
Mengistu DK, Kiros AY, Pè ME. 2015. Phenotypic diversity in Ethiopian durum wheat (Triticum turgidum var. durum) landraces. Crop J 3 (3): 190-199. DOI: 10.1016/j.cj.2015.04.003.

Morris EK, Caruso T, Buscot F, Fischer M, Hancock C, Maier TS, Meiners T, Müller C, Obermaier E, Prati D, Socher SA, Sonnemann I, Wäschke N, Wubet T, Wurst, S Rillig MC. 2014. Choosing and using diversity indices: Insights for ecological applications from the German biodiversity exploratories. Ecol Evol 4 (18): 3514-3524. DOI: $10.1002 /$ ece 3.1155

Mursyidin DH, Purnomo, Sumardi I, Daryono BS. 2019. Phenotypic diversity of the tidal swamp rice (Oryza sativa L.) germplasm from South Kalimantan, Indonesia. Aus J Crop Sci 13 (03): 386-394.

Mursyidin DH, Nazari YA, Daryono BS. 2017. Tidal swamp rice cultivars of South Kalimantan Province, Indonesia: A case study of diversity and local culture. Biodiversitas 18 (1): 427-432. DOI: $10.13057 /$ biodiv/d180155

Nayar NM. 2014. Origins and Phylogeny of Rice. Elsevier Inc., Oxford, UK

Nkamleu GB. 2011. Extensification versus intensification: Revisiting the role of land in African agricultural growth. African Economic Conference, October 2011.

Ortiz-Burgos S. 2016. Shannon-Weaver Diversity Index. In: Kennish MJ. (eds) Encyclopedia of Estuaries. Encyclopedia of Earth Sciences Series. Springer, Dordrecht, Netherlands.

Silva F, Stevens CJ, Weisskopf A, Castillo C, Qin L, Bevan A, Fuller DQ. 2015. Modelling the geographical origin of rice cultivation in Asia using the rice archaeological database. PLoS One 10 (9): e0137024. DOI: 10.1371/journal.pone.0137024

Sinaga PH, Trikoesoemaningtyas, Sopandie D, Aswidinnoor H. 2014. Screening of rice genotypes and evaluation of their ratooning ability in tidal swamp area. Asian J Agric Res 8: 218-233.

Song X, Cao X. 2017. Transposon-mediated epigenetic regulation contributes to phenotypic diversity and environmental adaptation in rice. Curr Opin Plant Biol 36: 111-118. DOI: 10.1016/j.pbi.2017.02.004.

Sulakhudin, Hatta M. 2018. Increasing productivity of newly opened paddy fields in tidal swampy areas using local specific technology. Indonesian J Agric Sci 19 (1): 9-16. DOI: 10.21082/ijas.v19n1.2018.p9-16

Turner-Hissong SD, Mabry ME, Beissinger TM, Pires JC. 2020. Evolutionary insights into plant breeding. Curr Opin Plant Biol 54: 93-100. DOI: 10.1016/j.pbi.2020.03.003

Uddin MN, Obara M, Yanagihara S, Ishimaru T, Kobayashi N, Fukuta Y. 2016. Genetic characterization of introgression lines with the genetic background of the Indica-type rice (Oryza sativa L.) cultivar IR 64 under irrigated lowland and upland conditions. Field Crops Res 191: 168-175. DOI: 10.1016/j.fcr.2016.03.007

Wahdah R, Langai BF. 2011. Initial selection of local rice varieties in the tidal swamps of Barito Kuala and Tanah Laut Regencies, South Kalimantan, as material of mutation. Agroscientiae 18 (3): 44-50. [Indonesian]

Wijayawardhana HCD, Herath HMVG, Weerasinghe PA, Herath HMDA. 2015. Morphological variation in selected Sri Lankan rice (Oryza sativa L.) accessions in relation to the vegetative parameters. Trop Agric Res 26 (2): 380-389.

Wu LL, Liu ZL, Wang JM, Zhou CY, Chen KM. 2011. Morphological, anatomical, and physiological characteristics involved in development of the large culm trait in rice. Aus J Crop Sci 5 (11): 1356-1363.

Zhang P, Li J, Li X, Liu X, Zhao X, Lu Y. 2011. Population structure and genetic diversity in a rice core collection (Oryza sativa L.) investigated with SSR markers. PLoS One 6 (12): e27565. DOI: 10.1371/journal.pone.0027565.

Zhao H, Fu YH, Wang X, Zhao C, Zeng Z, Piao S. 2016. Timing of rice maturity in China is affected more by transplanting date than by climate change. Agric For Meteorol 216: 215-220. DOI: 10.1016/j.agrformet.2015.11.001

Zheng J, Zhang Y, Wang C. 2015. Molecular functions of genes related to grain shape in rice. Breed Sci 65 (2): 120-126. DOI: $10.1270 /$ jsbbs.65.120. 